\title{
The Influences of the Internalization of International Structure to Malaysia's National Security
}

\author{
Chen $\mathrm{Ou}$ \\ School of Social Science, Universiti Sains Malaysia \\ Sungai Dua 11800, Pulau Pinang, Malaysia \\ E-mail: mrchenou@gmail.com
}

Received: October 10, 2011

Accepted: November 13, 2011

Published: March 1, 2012

doi:10.5539/ass.v8n3p151

URL: http://dx.doi.org/10.5539/ass.v8n3p151

The research is financed by Universiti Sains Malaysia Research Grant (PRGS)

\begin{abstract}
Constructivist structure is a sociological structure which represents the distribution of ideas. To most extents, ideas structure guides national security. In the level of international structure, Malaysia's national security has been influenced by two kinds of international "shared ideas": the internalization of the trend of democratization with "administrative accountability" and the internalization of the trend of Islamization. The internalization of international structure has three types to impel Malaysia's national security: be forced to accept, passively accept, and proactively accept. In the future, the further closer ties between Malaysia and international community, international structure will further impel Malaysian national security.
\end{abstract}

Keywords: Malaysia national security, Malaysia politics, National security, Ideas structure, Constructivism

\section{Introduction}

Malaysia is a federal constitutional monarchy in Southeast Asia. Malaysia is located in the south of the South China Sea and guarding the Strait of Malacca which is one of the most important sea lines connecting the Pacific Ocean and the Indian Ocean. Malaysia is an important member of ASEAN. In addition, Malaysia is a Muslim state which has kept close religious relations with Arabic states. Furthermore, as a British former colony, Malaysia is a member of the British Commonwealth. As a small and middle-sized country, Malaysia's national security is easily affected by international structure. The factor of ideas is the most significant component of international structure. The transformation of international structure (ideas) influences Malaysia's national security via the form of internalization. It is meaningful to analyze Malaysia's national security from the perspective of ideas of international structure.

\section{The dialectic relations of Ideas structure and national security}

National security is one of the essential requirements of states. So far, the recognized definition on national security is not yet given by academic circles. Arnold Wolfers defined "security, in any objective sense, measures the absence of threats to acquired values, in a subjective sense, the absence of fear that such values will be attacked" (Wolfers, 1962:150). From the view of cognition, this definition reveals two sides of national security: states in their safety objectively and states feel safe subjectively. The objective safety can be reflected from other states' subjective feelings on security. Unlike Realist structure by material, Constructivist insisted on the structure by ideas. Though material is an indispensible component in structure, ideas play the most significant role in structure. Thus, "the most important structures in which states are embedded are made of ideas, not material forces". (Wendt, 1999:309) From the perspective of national security, national interests are the objectives of national security. But, "the contents of national interests are largely a function of ideas". (Wendt, 1999:96) Thus to most extents, ideas structure constructs national interests which determine the direction of national security. Under national interests, interactions of states are employed to achieve each national security. The interactions of states appear as diplomacy, economic activities, cultural exchange, military actions, and so on. The most significant production of these interactions is "shared ideas" (Wendt, 1999:142) in the form of 
discourse, norms, ideology, etc. These "shared ideas" internalized into these states' internal structure via domestic law, domestic "shared ideas", national policies, etc. (Yuan, 2005; Katzenstein, 1996; Wendt. 1999)

Internalization is the path which international "shared ideas" enter into states' interior structure. How does internalization effect in this transformation from exterior structure into interior structure? Wendt listed three pathways to produce internalization: “'force', 'price', and 'legitimacy"” (Wendt, 1999:250). Actually, Wendt's three pathways are the equivalent of three types of cognition of states: be forced to accept, passively accept, and proactively accept. Among of the three types, the type of "be forced to accept" is against the will of accepted states, thus it is the most unstable on the process of the internalization of international "shared ideas". The type of "proactively accept" makes the high level "identification" on "shared ideas" between interior and exterior, thus it has the most stabilization on the process of the internalization of international "shared ideas".

\section{The internalization of international structure and Malaysia's national security}

International structure is in a dynamic transformation. At the same time, "shared ideas" of international structure have certain stability in the process of the transformation of international structure. From the view of Malaysia's national security, the two major "shared ideas" are playing significant role through the form of internalization. It is discussed in the following two points.

\subsection{The internalization of the trend of democratization with "administrative accountability"}

With the end of the Cold War, ideology has no longer played dominated role in international politics. The political and military confrontation has no longer been the most urgent topic on international political agenda. The competitions between states appear in national comprehensive strength. The citizen put more expects on their government's controlling capability. Democratic system in politics and economy is still the necessary and essential requirement for citizens. The performance of administration is raised to the prior position in citizen's minds. Citizens as well make use of all kinds of measures to express their thinking and ideas on governments. Specially, they make use of new media methods, such as facebook, micro-blog, and so on. These new methods broke out the traditional controlling of administrations and effectively reflected public opinion. For instance, in the color revolution in Central Asia and the Arabic democratic reformation, citizens called on to overthrow their autocracies and to establish democratic governments. And in the large riots in West European states, the citizens strongly criticized the false policies by the current administrations. The concept of democracy is sublimated into a higher level - democracy with "administrative accountability".

Malaysia had gradually been a colony of the United Kingdom since 1795. (Andaya \& Andaya: 136) At the end of the subsequently colonial history with more than one and half century, the United Kingdom left three significant legacies for Malaysia. The first legacy is the thought of democracy. It made the fact that democracy and free has been wide accepted by most of Malaysian. The second legacy is an effective political system based on Westminster parliament. It is the foundation of Malaysia's democratic politics. The third legacy is the ethnic party system. It produced "a party system based on single ethnic". (Chen, 2009:11) These three legacies provided a platform for the development of Malaysia's democratic politics. Meanwhile, it as well ensured a long-term national stability for Malaysia after its independence. As early as the period of colony, ethnic conflicts between Malay and non-Malay were the core political issue. For the independence of Malaysia, Malay had to accept the citizenship of non-Malay as well as non-Malay had to accept "Hak Istimewa Melayu". (Xiao, 1995) After the independence, the topic on ethnic interests has been used by the National Front (especially the United Malays National Organization (the UMNO)) to gain over the votes from Malay. On the other hand, Malay as well regarded the National Front headed by the UMNO as their protector of "Hak Istimewa Melayu". Thus, the UMNO has often easily obtained the political supports from Malay. The topic of ethnic interests has always been successfully used to win the votes in the past decades. When this kind of low-cost political tactic became the matter of course in the minds of those leaders in the UMNO, the government by the UMNO as well walked towards the road of "hegemonism". The disregard to the living of the people, the low efficient of the administration, and the serious level of corruption has gradually aroused the dissatisfactory of the people. The Deputy Premier Najib at the time even figured "if we do not change, the people will 'change' us". (Goh, 2008) More than fifty-year democratic practices as well impelled the Malaysian transformation of the understanding to democracy. Entering the new century, democratic though with "administrative accountability" has impacted Malaysian gradually. The color revolution in the Central Asia and the anti-government protests in Middle East showed the power of the democracy with "administrative accountability". In the face of these events, Malaysian began to re-check the government's achievements under the new thinking. Malaysian began to estimate their government and officers via their achievements. In the 2008 Malaysian election, the National Front headed by the UMNO lost the absolute majority of $2 / 3$ in the parliament congress and the administration rights in five local 
states. It is a clear symbol that voters have already tired in the topic of ethnic conflicts. Learning from other states' political events, Malaysian attempted to make use of new media methods to express their voices. For instance, because the mainstream media are controlled by the government, Malaysia's opposition parties or citizens began to utilize new media to voice, such as YouTube, Facebook, Email, SMS, and personal blogs. (Deng, 2008)

This kind of internalization of international "shared ideas" of new democracy with "administrative accountability" as well produced effect to Malaysia's government. Firstly, a kind of senses of danger has been attaching to Malaysia's government. The overthrow of some Arabic states' and the Middle Asian states' governments made the leadership of the UMNO realize the importance and emergency of the transformation of their administrative methods. In a meeting of the National Front, the Premier Najib clearly appealed the member parties of the National Front to abandon old framework and turn to actively assist the government to resolve the problems from the people. (Sin Chew Daily, 2011:4) Secondly, it drove Malaysia's government to make new policies for improving people's livelihood and promoting economic development. In 2009, Malaysian government put forward the new logo - "Satu Malaysia" (One Malaysia) which is "a concept to foster unity in Malaysians of all races based on several important values which should become the practice of every Malaysian" (Malaysia Bernama, 2009). Later under the logo of "Satu Malaysia", Malaysian government carried out a series of new policies. The most important comprehensive policies are Government Transformation Programme - The Roadmap and Economic Transformation Programme - A Roadmap for Malaysia.

\subsection{The internalization of the trend of Islamization}

Islamic political scholar John L. Esposito divided Muslim states into three categories by the degree of Islamization: secular states (the separation of church and state), Muslim states (obey secular law, and partial Islamic law as state law, the supreme leader must be Muslim), and Islamic states (the theocracy with Islam). (Esposito, 1984:96) According to this rule, Malaysia is regarded as a Muslim state. It is Islamization of the procedure of from a secular state to an Islamic state. After the World War II, some Arabic nationalists failed in their attempts of the secularization and westernization. It impelled some Islamic scholars to rethink the future of Islamic states via the return to the principles of Islam. It led to the Islam Restoration Movement after the war. Further, the gap of the attitudes on the modern civilization produced two kinds of ideas on the Islam Restoration Movement: revivalism and modernism. (Dong, 2001) Essentially, the core objective of the two ideas is a return to the fundamentalist Muslim mind. The significant gap between them is the method of "return". Revivalism disagrees with all ideas away the Koran and essentially takes a negative attitude to modern civilization. Modernism as well insists on the Koran, but takes a relatively open attitude to modern civilization, such as Western advanced political system and economic system. In the 1970s, the successful in Iran Islamic Revolution enlarged the gap between the two ideas. Some revivalist walked toward extreme fundamentalism and pursued violence to establish the theocratic Islam state. Later, a series of "Islamic revolutions" took place in the Middle East in the 1970s and the 1980s. The most characteristic examples are the Taliban in Afghanistan and the Al-Qaeda's activities. After the 9/11 event, the extreme fundamentalism was hit and turned into a low ebb. Modernism began to rise in the Islam Restoration Movement. The Color Revolution in the Central Asia and the Democratic Revolution in the Arabic world clearly displayed the dominating role of modernism in the Islam Restoration Movement. Asking for democracy and freedom became the highest frequent words in the traditional Islam states in this period.

Malaysia is a particular Muslim state in the Islam world. Geographically, Malaysia lies on the edge of the Islamic world and actually is in the traditional scope of East Asian civilization. In the components of population, the population of Muslim and non-Muslim occupies half respectively, though Malaysia declared as "Muslim state". Politically, though the Islamic law is partially accepted into Malaysian national politics, the Western parliament party is still the most important framework of Malaysia's national political system. Actually, since the independent of Malaysia in 1957, the distribution of ethnic interests has been the higher priority than the religious issue in national political agenda. As a Muslim state with a secular democratic political system, Malaysia has always been influenced by international Islam Restoration Movement. The two main ideas of the Islam Restoration Movement have also been internalized into Malaysia's domestic "shared ideas" via three paths.

The first path is to proactively accept the major ideas of the Islam Restoration Movement. Firstly, the identity of religion made Malaysia's Muslim intend to accept this kind of internalization. The ideas of revivalism in the Islam Restoration Movement are more easily to resonate with the believers. This is why few opposite voices from Malay ethnic spoke out when the topic of "comprehensive Islamization in Malaysia" was launched every time. In addition, quite many religious leaders and even some politician once studied in the Middle East states, 
such as Nik Abdul Aziz Nik Mat as the spiritual leader of the Pan-Malaysian Islamic Party and Abdul Hadi Awang as the president of the Pan-Malaysian Islamic Party. The religious educational background and the actual living in the Middle East states drove them to practice the Islamic ideas. Actually, the Pan-Malaysian Islamic Party is the most motivated defender of the revivalist ideas of "Islam state in Malaysia". On the other hand, Malaysian government by the UMNO actively accepted the ideas of "modernism" in the Islam Restoration Movement. The combination of Islam and contemporary democratic thoughts ensured the long political stability and the economic development of Malaysia. The political reality of "half population of non-Muslim" and the fact of the serious social instability by extreme Islamic movements in some Muslim states drove them to more firmly believe the path of "modernism" in the Islam Restoration Movement.

The second path is to passively accept major ideas of the Islam Restoration Movement. The passively accept is based on the proper cost. In Malaysia, though the populations of Muslim and non-Muslim has always kept a balance. But all Malaysian citizens have to accept the political fact that Malaysia is a Muslim state and Muslim dominates Malaysian politics. This fact came from Article 153 of the Constitution of Malaysia which grants the Yang di-Pertuan Agong (King of Malaysia) to "safeguard the special position of Malays".(Note 1) The existence of this article came from so called "Malaysian social contract" - Malaysian Chinese and Malaysian Indian traded the admission to Hak Istimewa Melayu (the special position in Article 153) for their citizenship at the time of Malaysian independence. (Faruqi, 2008; Xiao, 1995) Thus, though Malaysian Chinese and Malaysian Indian have always been unsatisfied with their unfair position in Malaysia, "Malaysian social contract" has been a default political rule in Malaysia. On the other hand, the government headed by Malay has also accepted the ideas of "modernism" in the Islam Restoration Movement and has adopted warm policies on the issue of Malaysian Islamization.

The third path is forced to accept major ideas of the Islam Restoration Movement. The "Malaysia social contract" ensured Malay's initiative on the Islamization of Malaysia in de jure and politically. Any voice against the Islamization of Malaysia must be involve Article 153 of the Constitution of Malaysia, thus this kind of opposite would be regarded as a kind of unconstitutional action. It means that non-Muslim can not challenge the Islamization of Malaysia from the level of law. Further, the administration has been dominated by Malay's political parties, Malaysian Chinese parties and Malaysian Indian parties basically have been playing a secondary role in Malaysian politics. So, non-Muslim political forces have played a limited role to prevent national Islamization. In addition, because the fertility rate of Malay has always been higher than the fertility rates of Malaysian Chinese and Malaysian India, non-Muslim ethnics will be more difficult to influence Malaysian policy-making in future under the game rule of the Parliament system. Consequently, non-Muslim in Malaysia are forced to accept the trend of national Islamization in Malaysia. On the other hand, affected by international Islam Restoration Movement, Malaysian Muslim political forces as well want to push the Islamization in Malaysia. What the differences between these Malay political forces are only the degree of Islamization in Malaysia. But, the social instability in the Middle East states and the Central Asian Muslim states as well impelled Malay political forces to adopt the ideas of "modernism" to promote Malaysian Islamization. Any Malay political forces could not bear the terrible sequences if they imposed Malaysian Islamization to all citizens under the ideas of revivalism in the Islam Restoration Movement.

\section{Conclusion}

Ideas are the most important component of structure. Ideas play a significant role in the relations with international structure and national security. National security to most extents is affected by the form of the internalization of "shared ideas" of international structure. Malaysia is a Muslim state with secular tripartite political system in East Asia. Thus, Malaysia has been affected by the ideas of Western democracy thoughts and the ideas of Islamic thoughts. The internalization of the trend of democratization with "administrative accountability" drove Malaysian politics towards the road of "the cost of political policy determines national politics" which is replacing the existing "the cost of ethnic interests determines national politics". On the other hand, the internalization of the trend of Islamization is another distinct symbol to impel Malaysian national security by international factor of ideas. Affected by the ideas of the Islam Restoration Movement, Malay political forces have made use of their advantaged to carry out a series of warm activities for Malaysian Islamization. In general, Malaysia should take great care to face the challenges on Malaysian national security from these two kinds of internalization of international "shared ideas". In the future, the further development of globalization will provide more open platform for the internalization of international "shared ideas". 


\section{References}

Andaya, B. W. \& Andaya, L. Y. (2001). A History of Malaysia, (2 ${ }^{\text {nd }}$ edition). Palgrave Macmillan, pp.136.

Chen, O. (2009). The Status Quo and Prospect of Party Politics in Malaysia. Beijing: International Data Information, No. 6, pp.11.

Deng, K. P. (2008, March 16). The Rising of New Media, Producing Political Effect. Singapore: Lianhe Zaobao.

Dong, Zh. H. (2001). The Fundamentalism of the Islam Restoration Movement: the Origin of Reality and History. Beijing: Strategy and Management, No. 6.

Esposito, J. L. (1984). Islam and Politics. New York: Syracuse University Press, pp.96.

Faruqi, S. S. (2008). Document of Destiny: the Constitution of the Federation of Malaysia. Selangor: Star Publications Berhad.

Goh, R. (2008, October 5). Admin Glitches Will Be Corrected, Assures Najib. KL: New Straight Times.

Katzenstein, P. J. (eds.) (1996). The Culture of National Security: Norms and Identity in World Politics. US: Colombia University Press.

Malaysia, Bernama. (2009, June 15). National Unity Ultimate Objective of 1 Malaysia, Says Najib. KL: Malaysia National News Agency.

Singapore, Sin Chew Daily (2011, March 26). Najib Appealed the Member Parties of the National Front. Malaysia: Sin Chew Daily, Page 04.

Wendt, A. (1999). Social Theory of International Politics. UK: Cambridge University Press, pp.96,142,250,309. http://dx.doi.org/10.1017/CBO9780511612183

Wolfers, A. (1962). Discord and Collaboration. Baltimore Johns Hopkins University Press, pp.150.

Xiao, Zh. (1995). Let's History Speak - Review of the Period of Constitutional Government. KL: Documents and Studies, Vol.13.

Yuan, Zh. Q. (2005). The Sociological Turn of International Politics Theory. Shanghai: Shanghai People Press.

Note

Note 1. See the Constitution of Malaysia. 